\title{
Substance Abuse Protection Self-Efficacy of Students from Two Different Types of High Schools and Related Factors
}

\section{Hematoloji İki Farklı Lise Türündeki Öğrencilerin Madde Bağımlılığından Korunmada Özyeterlilik Düzeyleri ve Bununla İlişkili Faktörler Gaucher Hastalığı sıklığı}

\author{
Nükhet Kırağ', @ Ece Tanılmışoğlu² \\ 'Aydın Adnan Menderes University School of Nursing Faculty Department of Public Health Nursing, Aydın, Turkey \\ ${ }^{2}$ Adnan Menderes University School of Nursing Faculty Department of Public Health Nursing, Aydın, Turkey
}

\begin{abstract}
Aim: This study aims to investigate self-efficacy and the related factors of students enrolled in two different types of high schools regarding protection from substance abuse.

Material and Method:This study was conducted with 170 volunteer students enrolled in an Anatolian High School in city center and a Technical High School in district in the academic year 2018-2019. Data were collected using a sociodemographic characteristic form and Self-Efficacy Scale for Protection from Substance Abuse. Data were analyzed using SPSS 20.0 software, percentage, chi-square, t-test and Anova test for independent groups.

Results: The mean age of the participants was 15.2 \pm 0.85 . Of them, 58.8\% were female and $55.3 \%$ were enrolled in Anatolian High School, $11.8 \%$ both smoked and used alcohol. There was a significant relationship between the mean score on the SelfEfficacy Scale for Protection from Substance Abuse and gender, residence, mother's education background, income level, type of high school, alcohol and smoking habits $(p<.05)$. Substance abuse protection self-efficacy levels of the Technical High School students were lower than that of the Anatolian High School students.

Conclusion: At risk students of substance abuse were male, those with lower income, those living in districts and villages, the Technical High School students, smokers and alcohol users. The high-risk groups should be diagnosed early and be aware of the risk. Early intervention measures should be taken for highrisk groups. These high-risk groups in schools should be closely monitored and, if necessary, collaborated with the family.
\end{abstract}

Keywords: Substance abuse, secondary schools, smoking
Öz

Amaç: İki farklı lise türünde öğrenim gören öğrencilerin madde bağımlılığından korunmaya ilişkin özyeterlilikleri ve ilişkili faktörleri incelemektir.

Gereç ve Yöntem: Bu çalışma, 2018-2019 akademik yılında il merkezinde bir Anadolu Lisesi ve ilçede bir Teknik Liseye kayıtlı 170 gönüllü öğrenci ile yürütülmüştür. Veriler Sosyodemografik Özellik Formu ve Madde Bağımılı̆̆ına Karşı Korunma Özyeterlik Ölçeği kullanılarak toplanmıştır. Veriler, SPSS 20.0 yazııımı, yüzde, ki-kare, t testi ve bağımsız gruplar için Anova testi kullanılarak analiz edildi.

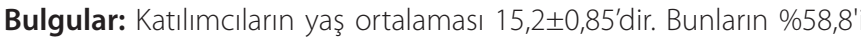
kadın, \%55,3'ü Anadolu Lisesi'ne kayıtlı ve \%11,8'i hem sigara hem de alkol kullanmıştır. Madde Bağımlılığından Korunma Öz-Yeterlilik Ölçeği puan ortalaması ile cinsiyet, ikamet edilen yer, annenin eğitim durumu, gelir düzeyi, lise türü, alkol ve sigara içme alışkanlıkları arasında anlamlı bir ilişki vardı $(p<.05)$. Teknik Lise'de öğrenim gören öğrencilerin madde bağımlılığından korunma öz yeterlik düzeyleri Anadolu Lisesi öğrencilerinden daha düşüktü.

Sonuç: Madde bağımlılığı açısından risk altındaki öğrenciler, gelir düzeyi düşük olanlar, ilçelerde ve köylerde yaşayanlar, Teknik Lise öğrencileri, sigara içenler ve alkol kullananlardır.Yüksek riskli gruplara yönelik erken müdahale önlemleri alınmalıdır. Okullarda yüksek riskli olan bu gruplar yakından takip edilerek gerekirse aile ile işbirliği yapılmalıdır.

Anahtar Kelimeler: Madde bağımlılığı, lise, sigara kullanımı 


\section{INTRODUCTION}

Substance use is an intoxicant preventing individuals from normal mobility and thought patterns with a narcotizing effect. ${ }^{[1]}$ This leads an individual to become dependent on the substance when used continuously. It causes addiction in the following periods. This can lead to certain mental problems when not used regularly. ${ }^{[2]}$ Drugs have an effect on the neurological system. Mental activities deteriorate and decreased attention span is observed. So, individuals experience mental disorders. Furthermore, narcotic drugs cause somnolence, thus individuals have less sensitivity to their environment. ${ }^{[2]}$

Although addiction has several meanings, it can be defined as an inescapable hunger for an object, a person or being under the influence of another will power. D opamine, a neurotransmitter, plays an important role in substance dependence. Substance use becomes attractive for people as it increases the level of dopamine. ${ }^{[3]}$ This dependency may take a long time and cause harm to the individual or others. This is a primary problem globally with many negative effects such as health problems, increase in health care expenditures, and increase in crimes resulting in social unrest. ${ }^{[4]}$

According to the 2016 report by the United Nations, there are 29 million substance abusers throughout the world. The report shows that nearly $5 \%$ of the adult population equaling 250 million people between the ages of 15-64 years used at least one narcotic drug in 2014. The number of substance abusers increased in the last six months from 27 million to 29 million, including around 12 million who used intravenous drugs. The report shows that men are three times more likely to use marijuana, cocaine or amphetamine than women. Conversely, women are more likely to use opioids or sedatives for non-medical purposes. The report shows the number of substance-user deaths were 85,900 in Asia, 52,500 in America, and 39,200 in Africa. ${ }^{[5]}$

Article according to Turkey Drug Report data was reported to be 11 years of age of first use. Turkey Drugs and Drug Addiction Monitoring Center (TUBIM), according to published by the conclusions of the report is, any drug cannabis, including the proportion of trying at least once (lifetime drug use prevalence) was found to be $1.5 \%$ in the $15-16$ age group.. ${ }^{[5}$ The belief in self-efficacy has a role in adolescents starting to take drugs and the continued use of them. The self-belief of an individual regarding whether they can overcome a problematic situation in life they are experiencing or will experience is called self-efficacy. This belief develops through observing other individuals within society and considering the opinions of others regarding events or experiences which adds to self-confidence. ${ }^{[6]}$

Self-efficacy is a self-judgment or belief that an individual has the ability to be successful in coping with possible difficult situations. It involves an individual's self-confidence and beliefs developed through experiences over time. Furthermore, people develop self-efficacy beliefs through observations or listening to other interpretations. ${ }^{[7]}$ The self-efficacy belief has an effect on adolescents' decision to start taking drugs and continue using them. ${ }^{[8]}$

This study aims to investigate self-efficacy and the related factors of students enrolled in two different types of high school types regarding protection from substance abuse.

\section{MATERIAL AND METHOD}

\section{Research Type}

This is a comparative descriptive study

\section{Setting and Time Period of the Study}

This study was conducted with 9th through 12th grade students enrolled in an Anatolian High School in the city center and a Technical High School in the district in the academic year of 2018-2019.

\section{Population and Research Sample}

Before the study, the minimum sample size was calculated to be 102 made on the basis of 0.05 margin of error, 0.80 power, and 0.50 effect size using g-power. The population of the study consisted of 800 students ( 450 girls, 350 boys) in Anatolian high schools and 500 students ( 320 girls, 180 boys) from Technical high schools. All students who volunteered to participate in the study without selecting the sample were included. The study was conducted with 170 students who were enrolled in two different types of high school and agreed to participate.

\section{Data Collection Tools}

The data were collected using a sociodemographic characteristic form and Self-Efficacy Scale for Protection from Substance Abuse.

Sociodemographic Characteristics Form This form consisted of 20 questions related to students' and their families' demographic information (age, gender, residence, type of high school, income status, smoking and alcohol habits, relationship within the family, loss of a relative, education background of the mother and father, etc.).

\section{Self-Efficacy Scale for Protection from Substance Abuse for Adolescents}

This was developed by Eker et al. (2012) and analyzed for validity and reliability of the study. ${ }^{[6]}$ The total internal consistency coefficient of the scale (Cronbach's) was .81. The internal consistency coefficient ranged between .45 and .87 in the subscales. The five-point Likert type scale included 24 items. The lowest possible score was 23 , and the highest was 120. A higher score indicated the students had self-efficacy regarding substance abuse protection. The scale had four subscales: staying away from drugs/stimulants, staying away from drugs/stimulants under pressure, seeking help regarding drugs/stimulants, and giving support to friends regarding drugs/stimulants. 


\section{Data Collection}

Data were collected by questionnaires and completed by students under observation at the schools. Names were not required on the questionnaires. Completing the questionnaire took around 15-20 minutes.

\section{Ethical Consideration}

Aydın Adnan Menderes University Nursing Department Ethics Committee of Non-Interventional Clinical Studies gave permission to conduct the study (2018/122). Approval of the Directorate of National Education and the school directorates as well as the written consent form of students and their parents were obtained.

\section{Data Analysis}

The data were analyzed using SPSS 16.0 software, percentage, chi-square, and t-test and Anova test for independent groups. Variables were adapted to normal distribution using Kolmogrov Smirnov test. The significance level was taken as $\mathrm{p}<.05$.

\section{RESULTS}

The mean age of the participants was $15.2 \pm 0.85$. Of them, $58.8 \%$ were female, $52.4 \%$ were living in the city center, $89.4 \%$ had a nuclear family structure, of their mothers $60.6 \%$ and $42.4 \%$ of fathers were primary school graduates, $64.7 \%$ of mothers did not work, $41.8 \%$ of fathers were laborers, $45.9 \%$ had a monthly income level above 2000 TRY, 58.8\% had equal income and expense.

Of the students, $55.3 \%$ were enrolled in an Anatolian High School, $88.2 \%$ of them described their relationships within the family as positive, $11.8 \%$ had smoking habits, $88.2 \%$ did not use alcohol, and $76.5 \%$ did not have a loss of a relative (Table 1).

The total mean score of the subscales were higher in female students than male students $(p<.05)$. Those who were 14 years old had significantly higher scores than other age groups from the scale and subscale $(p<.05)$ (Table 2$)$.

There was a significant relationship between the type of school and sociodemographic characteristics of the students in terms of smoking habits, alcohol intake, mother and fathers' education background, mother and fathers' profession, perception of family income level, family income level and type of high school $(p<.05)$. Smoking habits in the Technical High School students were significantly higher than those in the Anatolian High School $(p<.05)$.
Table 1. Sociodemographic characteristics of high school students

\begin{tabular}{|c|c|c|}
\hline $\begin{array}{l}\text { Variables } \\
\text { Age } 15.2 \pm 0.85 \text { (min:14, max:17) }\end{array}$ & $\mathbf{N}$ & $\%$ \\
\hline \multicolumn{3}{|l|}{ Gender } \\
\hline Female & 100 & 58.8 \\
\hline Male & 70 & 41.2 \\
\hline \multicolumn{3}{|l|}{ Residence } \\
\hline Province & 89 & 52.4 \\
\hline District & 63 & 37.1 \\
\hline Village & 18 & 10.6 \\
\hline \multicolumn{3}{|l|}{ Family type } \\
\hline Nuclear & 152 & 89.4 \\
\hline Single-parent & 18 & 10.6 \\
\hline \multicolumn{3}{|l|}{ Mother's education background } \\
\hline Illiterate & 5 & 2.9 \\
\hline Primary school & 103 & 60.6 \\
\hline High school & 45 & 26.5 \\
\hline University & 17 & 10.0 \\
\hline \multicolumn{3}{|l|}{ Father's education background } \\
\hline Illiterate & 7 & 4.1 \\
\hline Primary school & 72 & 42.4 \\
\hline High school & 56 & 33 \\
\hline University & 35 & 20.6 \\
\hline \multicolumn{3}{|l|}{ Mother's profession } \\
\hline Not working & 110 & 64.7 \\
\hline Laborer & 31 & 18.2 \\
\hline Office worker & 22 & 12.9 \\
\hline Shopkeeper & 7 & 4.1 \\
\hline \multicolumn{3}{|l|}{ Father's profession } \\
\hline Not working & 18 & 10.6 \\
\hline Laborer & 71 & 41.8 \\
\hline Office worker & 52 & 30.6 \\
\hline Shopkeeper & 29 & 17.1 \\
\hline \multicolumn{3}{|l|}{ Monthly family income level } \\
\hline Below 1000 TRY & 17 & 10 \\
\hline 1000-2000 TRY & 75 & 44.1 \\
\hline Above 2000 TRY & 78 & 45.9 \\
\hline \multicolumn{3}{|l|}{ Perception of family income level } \\
\hline Less income than expense & 31 & 18.2 \\
\hline Equal income and expense & 100 & 58.8 \\
\hline More income than expense & 39 & 23 \\
\hline \multicolumn{3}{|l|}{ High school } \\
\hline Anatolian High School & 94 & 55.3 \\
\hline Technical High School & 76 & 44.7 \\
\hline \multicolumn{3}{|l|}{ Relationship within the family } \\
\hline Positive & 150 & 88.2 \\
\hline Negative & 20 & 11.8 \\
\hline \multicolumn{3}{|l|}{ Smoking habits } \\
\hline Yes & 20 & 11.8 \\
\hline No & 150 & 88.2 \\
\hline \multicolumn{3}{|l|}{ Alcohol intake } \\
\hline Yes & 20 & 11.8 \\
\hline No & 150 & 88.2 \\
\hline \multicolumn{3}{|l|}{ Loss of a relative } \\
\hline Yes & 40 & 23.5 \\
\hline No & 130 & 76.5 \\
\hline
\end{tabular}


Table 2. The relationship of the self-efficacy scale for protection from substance abuse of high school students and the total mean score of the subscale with sociodemographic characteristics

\begin{tabular}{|c|c|c|c|c|c|}
\hline Variables & $\begin{array}{c}\text { Mean score on } \\
\text { staying away from } \\
\text { drugs/ stimulants }\end{array}$ & $\begin{array}{l}\text { Mean score on } \\
\text { staying away from } \\
\text { drugs/stimulants } \\
\text { under pressure }\end{array}$ & $\begin{array}{c}\text { Mean score on } \\
\text { staying away from } \\
\text { drugs/stimulants } \\
\text { regarding seeking } \\
\text { help }\end{array}$ & $\begin{array}{l}\text { Mean score on } \\
\text { staying away from } \\
\text { drugs/stimulants } \\
\text { regarding giving } \\
\text { support to friends }\end{array}$ & $\begin{array}{c}\text { Total mean score of } \\
\text { the scale }\end{array}$ \\
\hline Female & $55.06 \pm 8.38$ & $18.65 \pm 3.33$ & $16.78 \pm 4.39$ & $13.42 \pm 2.08$ & $107.73 \pm 16.27$ \\
\hline Male & $46.14 \pm 16.54$ & $15.78 \pm 5.86$ & $14.62 \pm 6.05$ & $10.97 \pm 4.66$ & $91.27 \pm 30.99$ \\
\hline P value & $.000^{*}$ & $.000^{*}$ & .008 & $.000^{*}$ & $.000^{*}$ \\
\hline 15 & $54.71 \pm 9.68$ & $18.34 \pm 3.70$ & $16.67 \pm 4.29$ & $13.02 \pm 2.92$ & $106.42 \pm 18.39$ \\
\hline 16 & $44.52 \pm 17.66$ & $16.17 \pm 5.71$ & $14.55 \pm 6.47$ & $10.92 \pm 4.62$ & $89.95 \pm 3.03$ \\
\hline 17 & $42.35 \pm 14.64$ & $12.28 \pm 7.06$ & $11.85 \pm 6.06$ & $11.14 \pm 4.41$ & $80.78 \pm 26.73$ \\
\hline$P$ value & .000 & .000 & .001 & .005 & .000 \\
\hline \multicolumn{6}{|l|}{ Residence } \\
\hline P value & $.002^{*}$ & $.008^{*}$ & $.031 *$ & $.002 *$ & $.002 *$ \\
\hline \multicolumn{6}{|l|}{ Mother's education background } \\
\hline Illiterate & $35.2 \pm 16.99^{* *}$ & $10.80 \pm 6.53^{* *}$ & $12.60 \pm 5.17^{* *}$ & $8.60 \pm 5.12^{* *}$ & $70.60 \pm 28.34^{* *}$ \\
\hline Primaryschool & $51.56 \pm 13.49$ & $17.31 \pm 4.92$ & $16.23 \pm 5.13$ & $12.30 \pm 3.65$ & $101.29 \pm 25.55$ \\
\hline High school & $53.51 \pm 10.79$ & $18.13 \pm 4.26$ & $15.91 \pm 5.45$ & $13.31 \pm 2.94$ & $104.71 \pm 21.72$ \\
\hline University & $49.47 \pm 12.99$ & $18.64 \pm 2.44$ & $14.76 \pm 5.17$ & $11.82 \pm 3.67$ & $97.88 \pm 21.83$ \\
\hline P value & $.026^{*}$ & $.007^{*}$ & .363 & $.028^{*}$ & $.030^{*}$ \\
\hline \multicolumn{6}{|l|}{ Income status } \\
\hline Less income than expense & $40.26 \pm 17.10^{* *}$ & $13.66 \pm 6.19^{* *}$ & $12.46 \pm 5.78^{* *}$ & $9.93 \pm 4.58^{* *}$ & $79.90 \pm 31.24^{* *}$ \\
\hline Equal income and expense & $53.98 \pm 10.81$ & $18.23 \pm 4.23$ & $16.61 \pm 5.01$ & $13.03 \pm 3.22$ & $105.89 \pm 21.46$ \\
\hline More income than expense & $52.71 \pm 11.04$ & $18.28 \pm 3.31$ & $16.42 \pm 4.44$ & $12.71 \pm 2.85$ & $103.36 \pm 18.98$ \\
\hline No & $52.36 \pm 12.45$ & $17.84 \pm 4.37$ & $16.20 \pm 5.07$ & $12.73 \pm 3.28$ & $102.82 \pm 23.39$ \\
\hline$P$ value & $.037^{*}$ & $.002 *$ & .090 & $.000^{*}$ & $.035^{*}$ \\
\hline \multicolumn{6}{|l|}{ Alcohol intake } \\
\hline Yes & $42.30 \pm 16.41$ & $13.85 \pm 6.69$ & $11.80 \pm 6.52$ & $10.05 \pm 4.57$ & $80.75 \pm 29.05$ \\
\hline No & $52.60 \pm 12.18$ & $17.95 \pm 4.22$ & $16.44 \pm 4.80$ & $12.72 \pm 3.33$ & $103.64 \pm 22.93$ \\
\hline P value & .001 & .000 & .000 & .002 & .000 \\
\hline
\end{tabular}

Alcohol intake in the Technical High School students was significantly higher than those in the Anatolian High School $(p<.05)$. In comparing school types based on mothers' education background, the education level of the students enrolled in Anatolian High School was higher than those in the Technical High School $(p<.05)$. Also, in comparing school types based on fathers' education background, the education level of the students enrolled in Anatolian High School was higher than those in the Technical High School $(p<.05)$. In comparing high school types based on fathers' profession, the number of unemployed fathers was higher in the Technical High School than in the Anatolian High School $(p<.05)$. The fathers of the students in the Technical High School worked primarily as laborers and the fathers of the students in the Anatolian High School worked primarily as office workers $(p<.05)$. A relationship was found between the perception of family income level and the type of high school $(p<.05)$. The numbers of those with a monthly income below 1000 TRY was higher in the Technical High School than the Anatolian High School $(p<.05)$ (Table 3). 
Table 3. Relationship of the students with the variables based on school type

\begin{tabular}{|c|c|c|c|}
\hline \multirow[b]{2}{*}{ Variables } & \multicolumn{2}{|c|}{ Type of high school } & \multirow[b]{2}{*}{ P value } \\
\hline & $\begin{array}{c}\text { Anatolian } \\
\text { High School }\end{array}$ & $\begin{array}{c}\text { Technical } \\
\text { High School }\end{array}$ & \\
\hline \multicolumn{4}{|l|}{ Smoking habits } \\
\hline Yes & 5 & 15 & .003 \\
\hline No & 89 & 61 & \\
\hline \multicolumn{4}{|l|}{ Alcohol intake } \\
\hline Yes & 4 & 16 & .001 \\
\hline No & 90 & 60 & \\
\hline \multicolumn{4}{|l|}{ Mother's education background } \\
\hline Illiterate & 0 & 5 & .000 \\
\hline Primary school & 48 & 55 & \\
\hline High school & 31 & 14 & \\
\hline University & 15 & 2 & \\
\hline \multicolumn{4}{|l|}{ Father's education background } \\
\hline Illiterate & 0 & 7 & .000 \\
\hline Primary school & 24 & 48 & \\
\hline High school & 40 & 15 & \\
\hline University & 30 & 5 & \\
\hline \multicolumn{4}{|l|}{ Mother's profession } \\
\hline Not working & 54 & 56 & .000 \\
\hline Laborer & 14 & 17 & \\
\hline Office worker & 20 & 2 & \\
\hline Shopkeeper & 6 & 1 & \\
\hline \multicolumn{4}{|l|}{ Father's profession } \\
\hline Not working & 5 & 13 & .000 \\
\hline Laborer & 24 & 47 & \\
\hline Office worker & 43 & 9 & \\
\hline Shopkeeper & 22 & 7 & \\
\hline \multicolumn{4}{|l|}{ Perception of family income level } \\
\hline Less income than expense & 10 & 20 & .003 \\
\hline Equal income and expense & 55 & 44 & \\
\hline More income than expense & 28 & 10 & \\
\hline \multicolumn{4}{|l|}{ Family monthly income level } \\
\hline Below $1000 \mathrm{TRY}$ & 3 & 14 & .000 \\
\hline 1000-2000 TRY & 31 & 44 & \\
\hline Above 2000 TRY & 60 & 18 & \\
\hline
\end{tabular}

\section{DISCUSSION}

The total mean score of the subscales of staying away from drugs/stimulants, staying away from drugs/stimulants under pressure, giving support to friends regarding drugs/stimulants were higher in female students than male students $(p<.05)$. Having friends who use substances and the level of becoming addicted was higher in men than in women. ${ }^{[9-11]}$ Şener et al. (2018) has stated that the knowledge level about addiction and self-efficacy of men was higher than women. ${ }^{[12]}$

Tunçbilek (2018) has discussed that substance abuse protection self-efficacy of male students was significantly higher than female students. ${ }^{[13]}$ The study by Osmanoğlu has indicated that women were more successful than men in staying away from drugs/stimulants. ${ }^{[14]}$
Since men have more freedom than women in regard to visiting places where substance use is more frequent, substance abuse by men may be viewed in the public eye as more acceptable than substance abuse by women. In line with the literature, this study indicated that female students are more conscious than male students regarding substance abuse protection..$^{[9-11,14]}$ Conversely, there are some studies discussing that males are more conscious than women regarding substance abuse protection. ${ }^{[12,13]}$

The substance abuse protection self-efficacy was higher in 14-year-old students than older students. Kurupınar \& Erdamar (2014) have stated that substance abuse and addiction to substance among 15-year-old students and older was more prevalent. ${ }^{[11]}$ Yüncü et al. (2014). The results of this study are in line with other studies. ${ }^{[15]}$ Thus, substance abuse protection decreases with increasing age. The reasons are adolescents endeavor to prove that they have grown up, want to gain acceptance by their friends, and they cannot refuse the offer of drugs from friends who are substance abusers. ${ }^{[9,11,16,17]}$

The mean scores on substance abuse protection self-efficacy of the students living in the city center were higher than those living in a village or district. There were no data regarding residence variable in the literature. The study by Osmanoğlu (2017) indicated that the participants living in the Black Sea and Central Anatolia region of Turkey attached more importance to expert opinion than those living in Eastern Anatolia and the Marmara region. Furthermore, those seeking help for drugs/ stimulants were living in the Black Sea and Mediterranean region, and those placing the least importance on that issue were living in the Central Anatolian region of Turkey. ${ }^{[14]}$ All the data for this study were collected from people living in the Aegean region of Turkey.

The high-level substance abuse protection self-efficacy of children living in the city center could be attributed to easy access to substance awareness activities within the school and parents' awareness of the issue.

The total mean scores of the subscale of the students whose mothers were high school graduates were significantly higher than those having secondary school graduate mothers. Tunçbilek (2018) has indicated that seeking help and giving support to friends regarding drugs/stimulants was higher among the participants whose mothers were unemployed than those having mothers working as public servants and self-employed. ${ }^{[13]}$ Mothers with higher education had a more positive affect on the substance abuse protection behaviors of children.

The total mean score of the subscale of those having an equal income and expense were higher than those having a lower income than expense. Tunçbilek (2018) has stated that seeking help regarding drugs/stimulants was signif-icantly higher in students having a monthly income between 3101 and 4600 TRY than those having an income between 1604 and 3100 TRY. The students with a weekly allowance of 81 TRY and above were found to stay away from drugs/stimulants 
and give support to their friends regarding drugs/stimulants significantly more than those receiving an allowance between 21 and 40 TRY. Students with a weekly allowance of 81 TRY and above were found to seek help regarding drugs/stimulants significantly more than those receiving an allowance below 40 TRY. Fur-thermore, students with a weekly allowance between 61 and 80 TRY and above were found to seek help regard-ing drugs/stimulants significantly more than those receiving an allowance between 21 and 40 TRY. ${ }^{[13]}$ Increase in the family income level increased the awareness of children about substance abuse protection.

The total mean score of the subscale of the students enrolled in Anatolian High School were significantly higher than those of the students enrolled in the Technical High School. The study by Osmanoğlu (2017) investigating students' avoidance of drugs/stimulants based on the school type indicated that the students enrolled in Science High Schools developed a more positive attitude towards substance abuse protection than any other type of high school. ${ }^{[14]}$ Şener et al. (2018) discussed that the addiction knowledge score measured in Anatolian High School and vocational school for girls and the total score on self-efficacy were significantly higher than those in the industrial vocational high school. ${ }^{[12]}$ The results obtained in this study show similarities with other studies. Substance abuse protection self-efficacy of students enrolled in the Technical High School is affected negatively. Students in the Technical High School form a high-risk group regarding substance abuse. The families' socio-economic level, parents' awareness regarding substance abuse, the amount and effectiveness of school activities on informing stu-dents about substance abuse have an important effect. ${ }^{[12]}$ The number of students selected based on certain cri-teria or enrolled voluntarily in vocational high schools is limited. Students enrolled in these schools are individuals who have not considered continuing higher education, wanted to have an occupation in a short period of time or because their parents wanted them to register. ${ }^{[18]}$ Students who do not obtain a sufficient grade to be enrolled in general high schools tend to enroll in these schools to be able to start their professional life as soon as possible. In brief, voca-tional high schools host students primarily with low income and education, from rural areas, and with crowded family structures. ${ }^{[19]}$

The total mean scores of substance abuse protection selfefficacy of the students who did not smoke were high-er than those who smoked. Similarly, the total mean scores of the students who did not use alcohol were higher than those who did. A higher substance abuse protection self-efficacy provides better protection against sub-stances which lead to addiction such as cigarettes and alcohol. Kılıç identified the number of those smoking eve-ryday as $23.6 \%$; the biggest reason for starting to smoke was curiosity (28.4\%) and the effect of friends (21.6\%). A study conducted with 13,438 students indicated that $34.4 \%$ of students first experienced alcohol with their friends and $8.4 \%$ experienced it on their own. Among the reasons for alcohol intake were trial, curiosity, sorrow, anger and fun. ${ }^{[20]}$ The major reason for starting to use alcohol at puberty was either peer pressure or it shows they have grown up and become sophisticated. Some adolescents use substances to rebel against their parents or so-ciety. Most adults and adolescents use alcohol to feel high or smoke because they believe smoking helps to re-lieve tension. ${ }^{[21]}$

\section{CONCLUSION}

Substance abuse protection activities should be increased in schools. Also, the students at risk and enrolled espe-cially in the Technical High School should be identified. It is suggested to conduct educational intervention re-search on substance abuse protection oriented at adolescents. Adolescents who are at risk for substance use should be identified and awareness training should be provided.

\section{ETHICAL DECLARATIONS}

Ethics Comittee Approval: Aydın Adnan Menderes University Nursing Department Ethics Committee of Non-Interventional Clinical Studies gave permission to conduct the study (2018/122).

Informed Consent: Written informed consent was obtained from all participants who participated in this study.

Status of Peer-review: Externally peer-reviewed.

Conflict of Interest Statement: The authors have no conflicts of interest to declare.

Financial Disclosure: The authors declared that this study has received no financial support.

Author Contributions: All of the authors declare that they have all participated in the design, execution, and analysis of the paper, and that they have approved the final version.

\section{REFERENCES}

1. Turkish Language Society glossary. Available from URL: http:// www.tdk gov.tr/.

2. Kaygısız M. Forensic Sciences. 5th ed. Ankara: Seçkin publications; 2005 p.6-10.

3. Öztürk O, Uluşahin A. Mental Health and Disorders. Ankara: Psychiatric Society Journal. 2015; 11:6-30.

4. Volkow N. D. M.D. Drugs, Brains, And Behavior The Science Of Addiction. National Instituted On Drug Abuse.[cited 2018 Oct 20]; 2(1). Available from URL: https://www.Drugabuse.Gov/ Sites/Default/Files/Soa_2014. Pdf.

5. Green Crescent (2017). Available from: http://www.yesilay.org.tr/tr/ haberler/detay/2016-dunya-uyusturucu-raporu-aciklandi.

6. Eker F, Akkuş D, Kapısız Ö. Development and psychometric evaluation of substance dependence self-efficacy scale for adolescents. Journal of Psychiatric Nursing. 2013 4(1): 7-12

7. Yardımcı F, Başbakkal Z. Validity and reliability study of secondary school self-efficacy scale. Journal of Anatolian Psychiatry. 2010;11:321-6.

8. Carpenter CM, Howard D. Development of a drug use resistance selfefficacy (DURSE) scale. Am J Health Behav. 2009;33:147-57.

9. Arslan H. N, Terzi Ö, Dabak Ş, Pekşen Y. Smoking, Alcohol and Substance Use in High School Students in. Erciyes Medical Journal. 2012;34(2): 79-84. 
10. Boyacı H, Çorapçıoğlu A, llgazılı A, Başyiğit I, Yıldız F. Evaluation of Smoking Habits of Kocaeli University Students. Journal of respiratory diseases. 2003; 14:169-175.

11. Erdamar G, Kurupınar A. Habit Addiction and Prevalence of Secondary School Students: The Case of Bartin Province. Journal of Social Sciences. 2014; 16(1): 65-84.

12. Şener D. K, Akkuş D. Factors affecting high school students' substance abuse behaviors. Addicta:The Turkish Journal on Addictions. 2018; 5(3):125.

13. Tunçbilek M. 15-18 yaş arası öğrencilerin madde bağımlılığından korunma öz yeterliliğinin araştıııması[Ph.D. thesis] University of Bartın; 2018; p. 25-9.

14. Osmanoğlu D. E. To determine the reasons of drinking and drug addiction self-efficacy behaviors of university students and their opinions on the causes of drinking. Atatürk University Kazım Karabekir Journal of Faculty of Education. 2017; 35(3):198-222.

15. Yüncü Z, Saatçıoğlu H, Aydın C, Özbaran N. B, Altıntoprak E, Köse S. (2014). The Legend of a City: Is the Age of Beginning to Use Dropping?.[cited 2018 Oct 15] Availablefrom:http://www. literatursempozyum.com:http:// www.literatursempozyum. com/pdf/m_1420637421.pdf.

16. Akkus D, Karaca A, Konuk Sener D, Ankaralı A. Smoking and alcohol use among high school students and factors affecting the frequency. Anadolu Clinic Journal. 2017;22(1):36-45.

17. Ünlü A, Evcin U. Evaluation of Drug Use Prevalence, Risk and Protection Factors Between 2008 and 2010 in. Anadolu University Journal of Social Sciences. 2014;14(3):127-140.

18. Dönmez F, Azizoğlu N. Examination of the scientific process skill levels of students in vocational high schools: Balıkesir case. Necatibey Faculty of Education Journal of Electronic Science and Mathematics Education. 2010; 4(2):79-109.

19. Günbayı I, Tokel A. Manager, teacher and student opinions about the effectiveness of vocational courses in technical and vocational high schools. Journal of Educational Research. 2014;3(4): 59-73.

20. Kılıç N. Adnan Menderes University Health School and Health Services Vocational School students' knowledge, attitude and behavior related to smoking. Journal of Health Sciences. 2006; 15(2): 87.

21. Essau C. A. Concluding remarks. In Substance Abuse and Dependence in Adolescence, Routledge.: 2014, pp. 241-256. 